\title{
Konsep Metafisika dalam Falsafah Jawa Hamemayu Hayuning Bawana
}

\author{
Dela Khoirul Ainia ${ }^{1}$ \\ Magister Ilmu Filsafat, Universitas Gajah Mada Yogyakarta, Indonesia \\ E-mail: Dela.khoirul.a@mail.ugm.ac.id
}

\begin{abstract}
Abstrak
Perkembangan zaman yang ditandai dengan bergesernya nilai dan ajaran falsafah lokal menjadikan menjadikan manusia tidak memahami pentingnya relasi terhadap Tuhan, manusia dan alam, sehingga dalam hidup akan merasa hampa dan kurang bernilai. Penelitian ini secara garis besar bertujuan untuk memahami konsep falsafah jawa Hamemayu Hayuning Bawana yang selama ini menjadi pandangan hidup masyarakat jawa berdasarkan pandangan metafisika. Penelitian ini merupakan penelitian kualitatif yang bersumber dari pustaka yang relevan.Manusia dalam hidup dipahami sebagai pelaku metafisika, karena menyadari keberadaannya bagi diri sendiri maupun bagi orang lain. Masyarakat Jawa dalam mencapai kebahagiaan hidup akan memandangan berdasarkan sudut pandang yang tidak hanya melalui dirinya namun juga di luar dirinya. Dalam hal ini manusia hidup berdampingan dengan alam dan tidak dapat dipisahkan dari unsur yang lain. Manusia dapat bereksistensi karena ada perantara pengada dalam suatu realitas.
\end{abstract}

Kata kunci: memayu hayuning bawana; metafisika; pengada.

\begin{abstract}
The development of the times characterized by the shifting values and teachings of local philosophy makes people do not understand the importance of relationships to God, man and nature, so that in life will feel empty and less valuable. This research is broadly aimed at understanding the concept of Javanese philosophy Hamemayu Hayuning Bawana which has been the view of javanese people's life based on metaphysical view. This research was conducted through qualitative approaches sourced from relevant libraries. Man in life is understood as a metaphysical subject and object, as well as a servant to himself or others. Javanese people in achieving the happiness of life will look at it based on the point of view not only through him but also outside him. In this case man coexisted with nature and could not be separated from the rest of the elements. Humans can exist because there is an intermediary in reality.
\end{abstract}

Keywords: memayu hayuning bawana; metaphysics; pengada.

\section{Pendahuluan}

Bangsa Indonesia merupakan bangsa yang memiliki kebudayaan dan berbagai nilai luhur yang digunakan sebagai pandangan hidup dan cerminan dalam berperilaku. Hingga saat masih banyak masyarakat yang menghayati dan menjalankan berbagai ritual yang berhubungan dengan nilai spiritualitas, karena dianggap sebagai langkah dan cara untuk memahami keberadaan Tuhan. Selain itu berbagai aktivitas dan ritual yang masih berkembang pada masyarakat Jawa merupakan sebuah cara untuk menyeimbangkan antara kehidupan manusia dengan alam. Masyarakat Jawa memiliki suatu kepercayaan bahwa terdapat kesatuan antara masyarakat, alam dan alam adikodrati yang terdapat dalam suatu kepercayaan bahwa suatu kejadian yang bersifat empiris akan berkaitan dengan hal yang bersifat adi kodrati atau metaempiris (Anas, 2013). Kebudayaan dan kearifan lokal yang hingga saat ini masih berkembang dan menjadi salah satu pegangan masyarakat kaitannya dalam berinteraksi dengan Tuhan, orang lain dan alam semesta yakni falsafah Hamemayu Hayuning Bawana. Masyarakat Jawa memahami konsep tersebut merupakan hal yang menjadi pedoman dalam berperilaku kaitannya dengan menjaga antara keseimbangan hidup manusia. Masyarakat Jawa dalam hidup memaknai bahwa kehidupan hanyalah sebentar atau diibaratkan mampir ngombe, hal yang singkat sehingga dalam menjalani kehidupan manusia hendaknya bersikap dalam kebaikan terhadap orang lain sebagaimana untuk dirinya sendiri. Menurut Dhiniaty (2015), manusia hidup di dunia bertujuan untuk menjadi pemimpin dan menegakkan kebaikan sehingga dapat tercapai tujuan kosmos dalam kehidupan. Masyarakat Jawa mengenal kehidupan yang berdampingan 
dengan tujuan harmoni, keadilan dan keteraturan hidup dengan sebuah konsep Tri Hita Kirana. Konsep tersebut memiliki makna hubungan antara manusia dengan Tuhan, manusia dan alam untuk mencapai kebahagiaan.

Berbicara mengenai metafisika tentu tidak dapat dilepaskan dari permasalahan mengenai yang ada dan realitas ada. Metafisika merupakan bidang kajian dalam ilmu filsafat, metafisika pernah menjadi primadona dalam perjalanan sejarah filsafat yakni pada masa abad pertengahan. Metafisika juga memiliki sumbangsih dalam perkembangan ilmu pengetahuan yang tidak banyak disadari. Penolakan terhadap metafisika didasari bahwa sesuatu hal dapat dikatakan ilmiah jika dapat dihitung, diukur, dan diverifikasi. Dalam pembahasan metafisika merupakan suatu hasil olah pikir yang mengatasi dan tidak menyentuh wilayah empirik positivistik (Mustansyir, 1997). Berbeda dengan hal tersebut metafisika merupakan bagian yang tidak dapat dipisahkan dari filsafat, karena menurut Whiteley metafisika merupakan essencial core dari filsafat sehingga metafisika ada di dalam setiap pemikiran filsafat (Whiteley, 1949; Wikandaru, 2017). Metafisika merupakan bagian dari filsafat, sehingga dalam hal tersebut filsafat diperlukan dalam kehidupan sehari-hari. Manusia dalam hidup berusaha untuk memperluas pemahaman maupun pengetahuannya namun terbatas, karena terdapat hal yang paling ideal yang tidak dapat dijangkau oleh tatanan pemahaman manusia. Akibatnya manusia akan berusaha untuk menemukan cara mencapai kehidupan yang diidealkan. Tidak sedikit diantaranya yang masih tidak yakin akan makna kehidupan dan arah tujuan yang akan dicapai dalam menjalani kehidupan (Titus, 1984). Terdapat beberapa pendapat dalam metafisika kaitannya dengan persoalan metafisika. Dalam hal ini dikemukakan oleh Sontag yaitu mengatakan bahwa persoalan metafisika sebenarnya tidak dapat dipisahkan satu dengan yang lain karena jawaban atas persoalan selalu berkaitan dan melahirkan persoalan yang baru. Menurut Sontag persoalan metafisika mengenai "ada" dan "bukan ada" (Wikandaru, 2013).

Masyarakat Jawa memiliki suatu konsep falsafah hidup yang masih berkembang ditengah modernitas kondisi kehidupan. Konsep falsafah jawa tersebut dipandang sebagai hal yang layak diteladani karen didalamnya terdapat filosofi yang berguna bagi keselarasan hidup. Konsep memayu hayuning bawana, bukan suatu ucapan biasa namun sebuah sandaran dalam masyarakat melakukan suatu tindakan. Memayu hayuning bawana, memiliki makna untuk menjaga memperindah, dan menyelamatkan dunia yang dicerminkan dari sikap dan perilaku masyarakat. Dalam kalangan masyarakat jawa ungkapan tersebut dipandang sebagai konsepsi hidup yang sakral. Dalam hal ini ungkapan tersebut mengandung makna yang mendalam dan daya mistis yang luar biasa. Falsafah Hamemayu hayuning bawana merupakan space culture dan spiritual culture. Dipahami dari space culture mengandung makna serentetan ruang (bawana). Bawana tidak lain merupakan sebuah alam jagad beserta isinya. Jagad dan isinya terkait dengan banyak terjemahan orang lain. Dalam tatanan wilayah kosmos bawana merupakan sebagai jagad rame yang banyak mengandung makna bahwa terdapat kehidupan manusia. Bawana dapat diibaratkan sebagai konsep hamparan luas kehidupan sekaligus mengandung makna taman luas setelah kematian kehidupan manusia. Dalam kehidupan hendaknya manusia berbuat kebaikan layaknya menanam kebaikan untuk dirinya sendiri (Endraswara, 2013).

Pada penelitian ini objek material yang dibahas konsep falsafah hamemayu hayuning bawana sebagai upaya untuk mencapai suatu keselamatan hidup di dunia maupun kehidupan batiniah. Puncak dari falsafah hamemayu hayuning bawana, yakni untuk meraih suasana tatatiti-tentrem atau kehidupan masyarakat yang disiplin dalam bertindak dicerminkan dalam kehidupan yang tentram dan damai kaitannya hubungan manusia dengan Tuhan, manusia dan alam sekitar. Saat masyarakat Jawa dapat menjaga keteraturan hidup antara alam semesta maka dapat mencapai suasana akan harmoni, tenang dan tentrem (memayu hayuning bawana) (Endraswara, 2013). Bentuk upaya untuk mencapai tujuan hidup tersebut memayu hayuning bawana (membangun kesejahteraan dunia atau menghiasi duunia) merupakan sebuah cara dalam manusia hidup untuk mencapai sebuah kesempurnaan hidup sehingga kelak akan meninggal secara sempurna (Wagiran, 2012). Pada penelitian ini, objek formal yang digunakan dalam menganalisis permasalahan tersebut yakni metafisika Anton Bakker, yaitu otonomi dan korelasi, sifat pengada, dinamika pengada serta kejasmanian dan kerohanian.

\section{Metode}

Penelitian ini mengunakan metode hermeneutika kefilsafatan. Bahan yang digunakan berasal dari data pustaka, sehingga penelitian ini merupakan penelitian pustaka. Data penelitian berasal dari dua sumber yang berbeda, yakni data primer dan data sekunder. Data sekunder 
merupakansumber kepustakaan utama yang digunakan dalam penelitian, sedangkan data sekunder merupakan merupakan literature pendukung yang digunakan untuk menunjang aktivitas penelitian (Kaelan, 2002). Adapun data primer yang digunakan dalam penelitian ini yakni karya Endraswara tahun 2014 yang berjudul Memayu Hayuning Bawana: Laku Menuju Keselamatan dan Kebahagiaan Orang Jawa. dan tulisan Wagiran tahun 2012 yang berjudul Pengembangan Karakter Berbasis Kearifan Lokal. Hamemayu Hayuning Bawana (Identifikasi Nilai-nilai Karakter Berbasis Budaya)teks ini berisi mengenai konsep memayu hayuning bawana sebagai upaya menyikapi fenomena kehidupan. Data sekunder dalam penelitian ini adalah beberapa bacaan literature dari berbagai sumber yang berkaitan dengan konsep metafisika. Data sekunder yang digunakan antara lain teks karya Anton Bakker tahun 1992 yang berjudul Ontologi atau Metafisika Umum Filsafat Pengada dan Dasar-dasar Kenyataan. Teks tersebut membahas mengenai konsep metafisika dan aliran-aliran yang terdapat dalam metafisika.

\section{Hasil dan Pembahasan}

\section{a. Konsep Falsafah Jawa Hamemayu Hayuning Bawana}

Manusia dalam hidup berdampingan dengan alam, sehingga manusia dapat menempatkan dirinya. Manusia dalam hidup merasa bagian dari tata kehidupan alam semesta, ada sebuah simbiosis yang saling menguntungkan antara alam dengan manusia. Perilaku manusia sangat menentukan keberlangsungan kehidupan hingga anak cucunya. Sejalan dengan hal tersebut masyarakat Jawa juga memiliki kearifan dalam hubungan antara dengan manusia dan dengan alam sekitar. Keduanya saling bergantung dan dapat membentuk suatu harmoni (Nugroho dan Elviandri, 2015). Melalui nilai kearifan masyarakat Jawa kemudian dituangkan dalam sebuah konsep dasar, bagaimana manusia berhubungan dengan Tuhan, manusia dengan manusia dan manusia dengan alam sekitar, sehingga akan terbentuk suatu kesepakatan bersama. Dalam konsepsi memayu hayuning bawana sebagai upaya untuk mencapai suatu keselamatan hidup di dunia maupun kehidupan batiniah. Mengutip dari pendapat Koentjaraningrat (1984) mengenai manusia dan alam menyatakan bahwa manusia memiliki kewajiban untuk berbuat kebaikan dan melanjutkan keindahan dunia yang telah ada dengan cara tidak merusakan dan mengotori kehidupan sehingga dapat mencapai kehidupan yang tentram dan harmoni. Falsafah hamemayu hayuning bawana yang menjadi salah satu pegangan hidup masyarakat Jawa menunjukkan bahwa manusia dalam interaksi antara alam dan manusia lain hendaknya bersikap arif, tidak merusak, dan memelihara apa yang telah alam sediakan. (Endraswara, 2013).

Konsep hamemayu hayuning bawana dapat diartikan dari kata hamemayu yakni memayungi dengan maksud menjaga dari segala hal yang mengganggu keamanan atau ketidaknyamanan yang disebabkan oleh kekacauan kehidupan Dalam hal ini yang dimaksud memayungi yaitu memayungi hayuning bawana, rahayuning jagad atau keselamatan dan kelestarian dunia dan seisinya. Sedangkan makna bawono merupakan hal yang dimaknai sebagai jagad sehingga filsafat tersebut mengandung makna global. Bawono yang harus dilindungi atau dijaga dapat dimaknai dalam lingkup dunia seisinya bahkan jagad raya (Mardjono, 2004; Wagiran, 2012). Jika dipahami melalui ajaran tersebut terdapat makna yang mendalam mengenai cara menjaga dan menyelamatkan dunia seisinya (Wagiran, 2012). Apabila dipahami melalui sisi kosmologis kejawen memayu hayuning bawana merupakan sebuah hamparan kehidupan jagad besar (makrokosmos) dan jagad kecil (mikrokosmos), yang memiliki makna kedua jagad tersebut wajib dijaga keselamatannya oleh manusia yang mendiaminya. Penting untuk dipahami bahwa kata Memayu memiliki makna menciptakan keselamatan atau kebagusan di jagad raya. Selain itu memayu dapat diartikan sebagai kata payu yang artinya menaungi (mengayomi). Memayu dalam konteks kosmos merupakan memperhatikan sedulur papat lima pancer yang merupakan bagian dari arah kiblat atau kepercayaan orang Jawa. Saudara empat itu berada pada titik kosmis yang strategis yaitu sawijining wangon dan salebeting wangon yang artinya di dalam diri kita terdapat saudara makdum sarpin yang dapat dimintai pertolongan disaat manusia sudah terjepit dalam situasi dan kondisi yang terpaksa (Endraswara, 2013). Apabila manusia dalam kehidupannya dapat mencapai suatu kondisi yang seimbang maka akan menghasilkan kehidupan yang selaras. Manusia akan memahami tempatnya dalam kehidupan di alam semesta ini, sehingga akan membentuk suatu perilaku yang sesuai dengan nilai norma yang berlaku kaitannya interaksi manusia dengan Tuhan, manusia, dan alam sekitar. 
Sebagai upaya mencapai kehidupan yang seimbang antara kehidupan manusia dengan sesama maupun dengan alam dan Tuhan maka diperlukan sebuah pengalaman hidup maupun pengalaman spiritual yang dapat memberikan gambaran dan penghati-hatian dalam menjalani kehidupan. Dalam hal ini terdapat beberapa strategi yang dapat diraih dalam mencapai hamemayu hayuning bawana. (1) berlatih untukmengolah diri pribadi, olah batin, dan olah rasa, (2) memahami mengenai interaksi sosial, (3) melakukan interaksi dengan Tuhan. Cara tersebut dapat dijalankan dalam kehidupan manusia dengan syarat dinalar, dirasa, dan dihayati sebagai sebuah sarana dalam pencapaian kedamaian dunia (Endraswara, 2013). Masyarakat jawa dalam tatanan kehidupan masih banyak terdapat berbagai ritual tradisi salah satunya, yaitu ritual untuk bertindak memayu hayuning bawana. Ritual tersebut dimaksudkan sebagai pengingat kepada pencipta hidup dalam hal ritual merupakan proses negosiasi untuk mendapatkan suatu keselamatan dengan tujuan untuk menyeimbangkan diri manusia dengan aspek makrokosmos. Sikap eling yang ditunjukkan oleh masyarakat jawa merupakan sebuah kesadaran dalam menjalani kehidupan kaitannya terhadap diri sendiri maupun pihak lain. Kesadaran tersebut terjadi dalam implementasi ritual yang sakral (Maula, 2013).

\section{b. Konsep Metafisika}

Membahas mengenai metafisika maka tidak dapat dilepaskan dari makna bahwa metafisika merupakan cabang filsafat keberadaan (being) atu eksistensi (existence). Metafisika merupakan ilmu yang bersifat umum, dalam arti berbeda dengan ilmu yang khusus karena metafisika tidak memiliki suatu bagian dari "yang ada" dan kemudian mengkaji satu bagian tersebut, melainkan mengkaji "yang ada" secara umum. Sehingga metafisika tidak mengkaji "yang ada" secara parsial, melainkan mengkaji semua yang memiliki posisi yang sama yakni sebagai "yang ada" atau sebagai "yang memiliki predikat ada" (Wikandaru, 2013). Metafisika Anton Bakker dapat dipahami melalui kerangka teoritis, yaitu sebagai berikut.

\section{1) Otonomi dan korelasi:kejamakan dan kesatuan}

Permasalahan mengenai otonomi dan korelasi merupakan persoalan yang fundamental yang menurut Anton Bakker ditempatkan dalam posisi yang pertama hal tersebut karena menyangkut aspek kuantitas dan realitas. Hal tersebut menyangkut mengenai kenyataan atau realitas terdiri dari jamak atau tunggal. Menurut pandangan Anton Bakker, merupakan suatu pertanyaan yang fundamental dalam bidang kajian metafisika. Aspek pertanyaan tersebut menyangkut dua aspek hal penting yakni aspek ekstensi yang berhubungan dengan pertanyaan apakah semua kenyataan bersifat majemuk atau tunggal. Selain itu, juga menyangkut aspek komperhensif kaitannya hubungan dengan pertanyaan apakah semua kenyataan itu memiliki kesamaan atau bermacam-macam (Bakker, 1992). Anton Bakker menempatkan persoalan mengenai otonomi dan korelasi dalam tatanan yang fundamental merupakan hal yang bukan karena sebab karena hal tersebut menyakut mengenai aspek kuantitas realitas. Permasalahan tersebut menjadi sebuah pertanyaan yang fundamental dalam metafisika dan menimbulkan berbagai spekulasi. Jawaban tersebut berorientasi pada monistis dan pluralistis yang merupakan dua aliran yang berusaha menjawab persoalan metafisika tersebut. Namun dalam menyikapi pertanyaan tersebut Anton Bakker memiliki cara tersendiri, menurutnya metafisika harus bertolak pada kenyataan konkrit, titik tolaknya yakni kesadaran manusia tentang dirinya sebagai data (Bakker, 1992).

\section{2) Sifat Pengada}

Menurut Anton Bakker metafisika memiliki tugas selanjutnya yakni menganalisis sifat pengada. Pengada dapat digunakan untuk merumuskan ontologi, dalam hal ini pengada dapat dimaknai melalui dua makna. Pertama, pengada dalam kedudukannya dapat sebagai data, kedua pengada berkedudukan sebagai realitas terdalam. Saat jawaban telah didapatkan terkait kenyaatan itu tunggal atau jamak maka untuk mendapatkan gambaran terkait struktur realitas maka metafisika memiliki tugas yakni menyelidiki sifat realitas yang menjadi sebuah hakikat terdalam (Wikandaru, 2013). Terkait dengan persoalan tersebut maka dapat diketahui melalui dua sikap pemahaman. Pertama, jawaban yang menganggap bahwa terdapat kesamaan sifat dalam sebuah pengada yang beda. Kedua, jawaban yang menganggap adanya beberapa sifat berbeda dalam sebuah pengada (Bakker, 1992). 


\section{3) Dinamika Pengada}

Permasalahan berikutnya dalam metafisika yaitu terkait dengan hasil pengamatan terhadap sebuah realitas yang ada dikarenakan sebuah pengada yang memiliki dinamika sendiri kaitannya terhadap eksistensi. Hal tersebut dapat ditemukan dalam kehidupan sehari-hari yakni seperti manusia, hewan maupun tumbuhan. Secara empiris dapat diamati mengenai dinamikanya yakni lahir, mati dan tumbuh. Berbeda dengan pengada lainnya seperti batu dan tanah, dinamika dalam benda tersebut tidak dapat dengan mudah diketahui karena dalam pengamatan tentu menimbulkan spekulasi jika batu dan tanah tetap dan tidak mengalami kematian. Menyikapi persoalan tersebut maka akan dihadapkan dengan sebuah pertanyaan yaitu sebuah pengada bersifat permanen atau hanya bersifat sementara (Bakker, 1992). Pertanyaan tersebut menimbulkan dua sudut pandang. Pertama, berkaitan dengan pertanyaan apakah yang ada akan selalu mengalami proses atau tidak. Kedua, berkaitan dengan pertanyaan apakah yang nampak atau ada eksistensinya melewati proses kelahiran dan kematian (Bakker, 1992).

\section{4) Kejasmanian dan Kerohanian}

Dalam bermetafisika dapat dimulai dari refleksi mengenai dua persoalan penting Pertama, problem mengenai kejamakan dan kesatuan kedua hal tersebut memiliki keterkaitan dengan aspek kuantitas dalam sebuah realitas. Kedua, terkait dengan aspek jasmani dan rohani yang memiliki hubungan terhadap kualitas realitas. Kedua persoalan tersebut sebagai penentu arah dalam menentukan kajian maupun diskusi ontologi (Siswanto \&Wikandaru, 2013). Problem terkait dengan kejasmanian dan kerohanian merupakan suatu persoalan yang telah melahirkan perdebatan panjang. Perdebatan tersebut menimbulkan sebuah jawaban dari para tokoh diantaranya. Pertama persepsi mengenai spiritualisme memandang bahwa realitas pada hakikatnya merupakan suatu roh yang tidak dapat diinderai manusia. Kedua, kelompok yang memandang bersifat jasmani. Ketiga, kelompok dualism yang memandang bahwa hakikat dari sebuah realitas sebagai bagian dari hakikat substansi jasmani dan rohani. Dalam menjawab pertanyaan tersebut Bakker, memiliki jawaban tersendiri yakni mengenai hakikat manusia. Sehingga dapat dipahami bahwa yang dapat memahi realitas kenyataan adalah manusia dan alam (kosmos) (Bakker, 1992).

\section{c. Tinjauan Metafisika dalam Konsep Falsafah Jawa Memayu Hayuning Bawana}

Kehidupan masyarakat khususnya masyarakat Jawa hingga saat ini masih memegang erat mengenai konsep falsafah jawa yakni hamemayu hayuning bawana. Konsep tersebut menunjukkan bagaimana cara manusia dapat hidup berdampingan dengan alam tanpa ada pihak yang dirugikan. Konsep memayu hayuning bawana merupakan suatu falsafah yang mengajarkan tentang mencapai keselamatan hidup dunia maupun dalam batin masing-masing. Falsafah tersebut menekankan bahwa masyarakat Jawa memandang kehidupan dunia yang di dalam maupun di luar dirinya sebagai langkah untuk mencapai puncak kebahagiaan jiwa. Hal tersebut dapat dicapai apabila seseorang memajami dan mengamalkan apa yang diajarkan melalui falsafah tersebut. Apabila merujuk pada pandangan metafisika Anton Bakker terkait dengan struktur realitas jasmani dan rohani dapat ditemukan sebuah perpaduan roh dan badan seseorang untuk mencapai sebuah realitas dan puncak kebahagiaan jiwa setelah melaksanakan ajaran dari falsafah memayu hayuning bawana. Apabila telah memahami dan melaksanakan falsafah hamemayu hayuning bawana maka akan membawa seseorang pada puncak kehidupan yakni mencapai sebuah kebahagiaan batin yang tidak dapat digambarkan melalui indera. Manusia sebagai pengada yang didalamnya terdapat beberapa bagian maupun struktur realitas maka hal tersebut merupakan sebuah sikap metafisik yang ditujukan bagi dirinya maupun kepada orang lain.

Falsafah hamemayu hayuning bawana apabila dipandang melalui otonomi-korelasi dan kejamakan-kesatuan maka masyarakat Jawa lebih sering memahami rasa dalam dirinya. Masyarakat Jawa tidak hanya memandang realita kehidupan melalui pandangan diri sendiri melainkan juga melibatkan sebuah realitas di luar dirinya (Marsono, 2019). Masyarakat Jawa dalam hidupnya kaitannya mengamalkan falsafah hamemayu hayuning bawana telah melakukan sebuah proses yakni pengada yang telah bermetafisika dan tidak akan berakhir karena manusia akan mengalami gejolak yang tidak stabil akibat berbagai pengaruh dalam diri. Implementasi falsafah hamemayu hayuning bawana pada masyarakat Jawa merupakan bahwa masyarakat telah memaknai realitasyang ada di dunia maupun di luar dirinya masing-masing. Akibatnya masyarakat Jawa saat memahami kehidupan realitas dunia yang terpisah maka akan 
menggunakan aktivitas mental untuk menghayati rasa dan mengamalkan falsafah tersebut. Jika dipahami makan akan menunjukkan terjadinya sebuah korelasi dari realitas dunia yang terpisah dari dirinya dunia di luar dirinya. (Marsono, 2019). Hasil dari pemahaman terhadap falsafah hamemayu hayuning bawana akan menghasilkan pada aktivitas rasa untuk mencapai sebuah kebahagiaan dalam diri.

Konsep hamemayu hayuning bawana lebih menekankan pada aspek kedamaian dan kerohanian, bahwa manusia harus dapat bersikap arif, tidak merusak dan memperlakukan alam layaknya memperlakukan manusia. Diri seseorang tidak dapat dipisahkan dari adanya interaksi dengan realitas yang ada di alam, meski sekilas konsep memayu hayuning bawana merupakan suatu falsafah yang sering diucap namun ternyata memiliki makna yang mendalam. Jika dipandang menggunakan metafisika mengenai aspek kejasmanian dan kerohanian merupakan suatu cara untuk memahami falsafah memayu hayuning bawana. Aspek kejasmanian dapat ditunjukkan melalui pemahaman dan sikap yang dicerminkan manusia dalam memperlakukan alam dan lingkungan sekitar. Sedangkan dalam aspek kerohanian akan ditimbulkan dari kenyamanan dan kedamaian diri seseorang setelah mengimplementasikan falsafah memayu hayuning bawana sebagai landasan dalam berperilaku keseharian. Manusia tidak dapat dilepaskan hubungannya dengan alam, sehingga apabila manusia melakukan kerusakan terhadap alam, maka demikian juga alam akan meresponnya melalui bencana yang akan merugikan kehidupan manusia.

Manusia dalam hidup di dunia berdampingan dengan alam, sehingga terdapat kesatuan antara manusia dengan alam. Sikap hamemayu hayuning bawana menjadi salah satu landasan dalam manusia melakukan interaksi dengan alam. Dalam hidup manusia tentu melakukan suatu usaha untuk mencapai suatu keinginan maka sama halnya dengan kehidupan yang damai tentu harus dilakukan suatu usaha untuk pencapaian. Apabila ditinjau menggunakan aspek otonomi korelasi dan kejamakan kesatuan akan menunjukkan bahwa masyarakat Jawa dalam memahami falsafah hamemayu hayuning bawana merupakan suatu realitas yang tidak terpisahkan dari kehidupan. Karena adanya kesatuan antara manusia dengan falsafah tersebut maka dalam akan selalu terpegang dalam prinsip hidupnya. Dilihat dari tatanan korelasi yakni akan merujuk pada aktivitas diri seseorang yang mempengaruhi kehidupan manusia, konsep memayu hayuning bawana yang masih terimplementasi dalam kehidupan masyarakat akan memberikan pengaruh terhadap jiwa individu, karena jika seseorang telah melaksanakan konsep hamemayu hayuning bawana dalam hidupnya maka akan merasa lebih damai dan tentram. Sehingga falsafah memayu hayuning bawana dapat dijadikan sebagai prinsip hidup dalam mengatur hidup guna mencapai keseimbangan antara manusia dengan alam.

Masyarakat Jawa dalam hidupnya masih memegang erat falsafah hamemayu hayuning bawana. Masyarakat jawa dalam melaksanakan falsafah hamemayu hayuning bawana masih diiringi dengan ritual maupun tradisi dengan tujuan mempersembahkan kepada Sang Pencipta. Hal tersebut jika dipahami melalui teori metafisika Anton Bakker maka terkait adanya hubungan kegiatan dan penyebaban. Persoalan mengenai pengada satu dengan pengada lain memiliki tiga hubungan sekaligus. Pertama, apakah salah satu pengada aktif akan menyebabkan pengaruh pengada yang lain. Kedua, apakah terdapat suatu pengada yang pasif akibat pengaruh pengada yang lain. Ketiga, apakah pengada menyebabkan pengaruh terhadap pengada yang lain. Menyikapi persoalan terkait adanya kegiatan dan penyebaban dengan hubungan pengada satu dengan pengada yang lainnya (Bakker, 1992). Masyarakat dalam mengimplementasikan hamemayu hayuning bawana tentu akan berusaha melaksanakan langkah-langkah di atas, maka melalui langkah tersebut terdapat keterkaitan antara strategi dan hasil yang dicapai.

\section{Simpulan}

Memayu hayuning bawana merupakan suatu falsafah yang masih terimplementasi dalam tatanan masyarakat Jawa, melalui falsafah tersebut diharapkan terjadi suatu keseimbangan antara kehidupan manusia dengan alam. Dalam konsepsi memayu hayuning bawana sebagai upaya untuk mencapai suatu keselamatan hidup di dunia maupun kehidupan batiniah. Kerangka teoritis metafisika Anton Bakker. Penelitian ini menekankan pada aspek otonomi-korelasi dan kesatuan-kejamakan, kejasmanian dan kerohian, dinamika pengada. Falsafah hamemayu hayuning bawana dikembangkan sebagai pengada diantara pengada-pengada yang lain. Pemahaman mengenai konsep hamemayu hayuning bawana memberikan implikasi terhadap kehidupan kaitannya hubungan manusia dengan alam. Falsafah hamemayu hayuning bawana merupakan ajaran hidup yang layak untuk dijadikan sebagai landasan dalam pengembangan diri, 
hal tersebut dapat diinternalisasikan pada diri masing-masing individu melalui berbagai jalur formal maupun informal. Jalur formal dapat dilakukan melalui pendidikan yang diajarkan di sekolah dengan praktik langsung. Selain itu keterlibatan orang tua, lingkungan tempat tinggal dan sekolah menjadi kunci utama dalam mencapai keberhasilan membentuk generasi yang menjaga dan melestarikan ajaran falsafah hidup masyarakat Jawa.

\section{Daftar Pustaka}

Anas, Mohamad. (2013). Telaah Upacara Kasada, Moitos dan Kearifan Hidup dalam Masyarakat Tengger. Kalam: Jurnal Studi Agama dan Pemikiran Islam Vol 7 No 1, h.21-52.

Bakker, Anton. (1992). Ontologi atau Metafisika Umum Filsafat Pengada dan Dasar-Dasar Kenyataan. Yogyakarta: Kanisius.

Endraswara, Suwardi.(2013). Memayu Hayuning Bawana: Laku Menuju Keselamatan dan Kebahagiaan Orang Jawa. Yogyakarta:Penerbit Narasi.

Gularso, Dhiniaty. (2015). Model Pembelajaran IPS Siswa Sekolah Dasar Berbasis Karakter Hamemayu Hayuning Bawono sebagai Salah Satu Upaya Mewujudkan Generasi Cerdas dan Berakhlak Mulia. Seminar Nasional Universitas PGRI Yogyakarta, h.236-245.

Kaelan. (2002). Metodologi Penelitian Kualitatif Bidang Filsafat. Yogyakarta: Penerbit Paradigma. Koentjaraningrat. (1984). Kebudayaan Jawa. Jakarta: Balai Pustaka.

Marsono.(2019). Prinsip Hidup Kawruh Begja dalam Perspektif Anton Bakker. Jurnal SANJIWANI Vol X No 2, h.104-116.

Maula, Finayatul. (2013). Asketisme Hidup Orang Jawa. Jurnal LoroNG, Vol 3 No 1, h. 127-132.

Mustansyir, Rizal (1997). Aliran-Aliran Metafisika. Jurnal Filsafat, h. 1-14.

Nugroho, Sigit Sapto dan Elviandri. (2015). Memayu Hayuning Bawana: Melacak Spiritualits Transendensi Hukum Pengelolaan Sumber Daya Alam Berbasis Kearifan Masyarakat Jawa.

Siswanto, Joko dan Reno Wikandaru. (2013). Metafisika Nusantara: Belajar Kehidupan Kearifan Lokal. Yogyakarta: Gadjah Mada University Press

Titus, Harold, Marilyn S. Smith dan Richard T Nolan. (1984). Living Issues in Philosophy. Alih Bahasa: H.M. Rasjidi Persoalan-Persoalan Filsafat.Jakarta:Bulan Bintang.

Wagiran. (2012). Pengembangan Karakter Berbasis Kearifan Lokal. Hamemayu Hayuning Bawana (Identifikasi Nilai-nilai Karakter Berbasis Budaya). Jurnal Karakter, Tahun II Nomor 3, h.329-339.

Wikandaru, Reno. (2013). Metafisika Serat Wirid Hidayat Jati. Yogyakarta: Fakultas Filsafat. 